\title{
5
}

\section{Effects of Two Novel Peptides from Skin of Lithobates Catesbeianus on Tumor Cell Morphology and Proliferation}

\author{
Rui-Li ZHAO',2, Jun-You HAN³, \\ Wen-Yu HAN ${ }^{2}$, Hong-Xuan HE${ }^{4}$ and Ji-Fei MA ${ }^{1}$ \\ ${ }^{1}$ Department of Animal Science, Tianjin Agricultural University, Tianjin \\ ${ }^{2}$ College of Animal Science and Veterinary Medicine, Jilin University, Changchun \\ ${ }^{3}$ College of Plant Science, Jilin University, Changchun \\ ${ }^{4}$ Research Center for Wildlife Borne Diseases, Institute of Zoology, \\ Chinese Academy of Sciences,
}

China

\section{Introduction}

The number of resistant bacterial strains has continued to increase due to the overuse of antibiotics, necessitating continued development of novel antimicrobial agents. These resistant strains have made the care of infected patients with cancer more difficult [1, 2]. Indeed, infection control in patients with malignant tumors is one of the most important aspects of hospital management. Amphibian skin secretions contain a large number of antimicrobial peptides, including aurein 1.2, citropin 1.1, gaegurins, magainin, and magainin analogues, which have shown selective toxicity against human cancer cells $[3,4,5]$. There are now 105 antitumor peptides listed in the antimicrobial peptide database (APD, http://aps.unmc.edu/AP), 11 of which were isolated by Roaek [6] from the Australian bull frogs. Most of the remaining peptides have been isolated from the family magainins [7] or from Xenopus laevis.

Antimicrobial peptides rely on amphiphilic a-helix structures to associate with prokaryotic lipid bilayers, often forming transmembrane ion channels that cause cell leakage, mitochondrial failure, or the activation of apoptotic signaling cascades. Antimicrobial peptides have little effect on healthy eukaryotic cells, however, and tend to act selectively on prokaryotic cells and damaged eukaryotic cells. Thus, they have the capacity to kill bacteria, fungi, and viruses. In addition, antimicrobial peptides can damage cancer cells without damaging normal cells, possibly due to differences in the composition of the cell membrane and cytoskeleton. Whether the antimicrobial peptides kill bacteria and tumor cells through the same molecular mechanisms is uncertain [8]. In recent years, antimicrobial peptides have becoming an intense focus of research in zoology, physiology, and pharmacology [9, $10]$, as these peptide are high efficiency, low toxicity, broad-spectrum antimicrobial agents that may complement traditional antibiotics.

We isolated two novel polypeptides named temporin-La [11] and palustrin-Ca with strong antimicrobial and antitumor activities by screening the skin cDNA library of Lithobates 
catesbeianus. In order to explore the antitumor mechanism of temporin-La and palustrin-Ca, we investigated the influence of these two polypeptides on HeLa ultrastructure by transmission electron microscopy. These two antimicrobial peptides are potential candidates for clinical trials as antibiotics and anticancer drugs.

\section{Materials and methods}

\subsection{Materials}

A Lithobates catesbeianus skin cDNA library was constructed in the Department of Microorganisms and Immunity, College of Animal Science and Veterinary Medicine, Jilin University. Tumor cells used in the anticancer assays were the gastric tumor cell lines SGC7901 and MGC-803, and the liver tumor cell lines SMMC7721 and BEL-7402. The tumor cells were obtained from the First Hospital of Jilin University. The Gram-negative bacteria Escherichia coli (ATCC 25922), Klebsislla pneumoniae (ATCC700603), Salmonella (ATCC20020), and Pseudomonas aeruginosa (ATCC227853), the Gram-positive bacterium Staphylococcus aureus (ATCC25923), Streptococcus suis 2 (CVCC606), Listeria (ATCC 54004), and Bacillus subtilis (ADB403), and the fungus Candida albicans (ATCC10231) were all obtained from China Institute of Veterinary drug Control.

\subsection{Peptide synthesis}

Temporin-La and palustrin-Ca were synthesized by GL Biochem (Shanghai, China) Ltd. according to the deduced amino acid sequences of mature peptides. High performance liquid chromatography and ESI-MS mass spectrometry confirmed that the purity of the synthetic peptides was higher than $95 \%$. The synthetic peptides were dissolved in sterile water and used to evaluate antimicrobial and antitumor activities.

\subsection{Antimicrobial assays}

Microorganisms were incubated in LB broth at $37^{\circ} \mathrm{C}$ to log-phase and then diluted in fresh LB broth to approximately $2 \times 10^{6} \mathrm{CFU} / \mathrm{mL}$. To test the dose-response of the peptides, $50 \mu \mathrm{L}$ samples of diluted microorganisms were mixed with 1:1 serial dilutions of the synthetic peptides in fresh LB in 96-well microtiter plates. Plates were incubated at $37^{\circ} \mathrm{C}$ in a moist atmosphere for 16-18 h. After incubation, the absorbance of the plates at $600 \mathrm{~nm}$ was measured and recorded. The minimal inhibitory concentration (MIC) of the peptides was defined as the minimal concentrations at which no visible growth of the microorganisms was detected [12].

\subsection{Hemolytic assays}

The hemolytic effect of the toxins was tested using rabbit erythrocytes in liquid medium according to a method previously described [13]. Briefly, serially diluted peptides were incubated with washed rabbit erythrocytes at $37^{\circ} \mathrm{C}$ for $30 \mathrm{~min}$. Following incubation, the cells were centrifuged and the $595 \mathrm{~nm}$ absorbance of the supernatant was measured. Absorbance was compared to that of supernatant from cells completely lysed with $1 \%$ Triton X-100.

\subsection{Transmission electron microscopy}

Transmission electron microscopy was performed to study the potential antitumor mechanisms of temporin-La and palustrin-Ca on HeLa cells. Briefly, the tumor cells were 
digested by trypsin and incubated in $50 \mathrm{~mL}$ cell culture flasks with toxin for $2 \mathrm{~h}$. Cells were then harvested and centrifuged. The cell pellets were embedded, stained, dehydrated, and embedded in white resin. The embedded cells were then sliced, stained, and imaged using a JEM-1200EXIl microscope under standard operating conditions.

\section{Results}

\section{1 cDNA cloning of temporin-La and palustrin-Ca}

Two bacterial clones encoding the two novel antimicrobial peptides were identified separately. The first clone encoded a mature peptide named temporin-La and the second encoded palustrin-Ca (Figure 1). The cDNAs were deposited in GenBank under accession numbers FJ430082 and FJ830669.

\section{Temporin-La}

atgttcccttgaagaaatccctgttactccttttttccttgggaccatcaacttatct 60

$$
\begin{array}{llllllllllllllllllll}
M & F & P & L & K & K & S & L & L & L & L & F & F & L & G & T & I & N & L & S
\end{array}
$$

Ttttgtgaggaagagagagatgtcgatcaagatgaaagaagagatgatccaggtgaaagg 120

$$
\begin{array}{lllllllllllllllllllll}
F & C & E & E & E & R & D & V & D & Q & D & E & R & R & D & D & P & G & E & R
\end{array}
$$

Aatgttcaagtggaaaacgattgttacgacatgttgtaaagattctcgaaaatatttg

\begin{tabular}{llllllllllllllllllll}
$N$ & $V$ & $Q$ & $V$ & $E$ & $K$ & $R$ & L & L & $R$ & H & V & V & K & I & L & $E$ & K & I & L \\
\hline
\end{tabular}

Ggaaataaccagaaatgttgaaactttgaaaatggaattggaaatcatttgatgtggaa

$\mathrm{G} \quad \mathrm{K} \quad *$

Tattatttggctaaatgctcaacagatgttttataaaaataaataaatatgttgcaaaaa

\section{Palustrin-Ca}

atgttcaccatgaagaaatccetgttgctcctttctttcttgggaccatctccttatct

\begin{tabular}{llllllllllllllllllll}
$G$ & $F$ & $L$ & $D$ & $I$ & $I$ & $K$ & $D$ & $T$ & $G$ & $K$ & $E$ & $F$ & $A$ & $V$ & $K$ & $I$ & $L$ & $N$ & $\mathbb{N}$ \\
\hline
\end{tabular}

Ttaaaatgtaaattggctggaggatgtccaccctgaatcagaagtcatctcatgtggaat

$\begin{array}{lllllllllllllllll}\mathrm{L} & \mathrm{K} & \mathrm{C} & \mathrm{K} & \mathrm{L} & \mathrm{A} & \mathrm{G} & \mathrm{G} & \mathrm{C} & \mathrm{P} & \mathrm{P} & *\end{array}$

Atcacttagctaaatctgtaatgtcttattaaaaaataaaaatatcacatgcaaaaaaa

Fig. 1. Nucleotide and deduced amino acid sequences of temporin-La and palustrin-Ca precursors. Sequences of the mature peptides are underlined. The asterisks represent the termination codon. 
The deduced amino acid sequences, net charges, molecular masses, and isoelectric points of temporin-La and palustrin-Ca are shown in Table 1. Temporin-La consists of 13 amino acid residues with a net charge of +3 at $\mathrm{pH}$ 7.0. The C-terminus of temporin-La is amidated. A NCBI-BLAST search revealed that the nucleotide sequences of the precursors of temporinLa exhibit $40 \%$ sequence identity with other temporin precursors from Rana species. Palustrin-Ca consists of 31 amino acid residues with a net charge of +2 at $\mathrm{pH} 7.0$. The seven peptide "Rana box" was formed by the Cys ${ }^{23}$ and $\mathrm{Cys}^{29}$. Palustrin-Ca demonstrated approximately 50\% homology with brevinin-2TD from the European frog and with ranatuerin-2Ca, ranatuerin-3, and ranatuerin $2 \mathrm{Cb}$ from bullfrog.

\begin{tabular}{llccc}
\hline & & $\begin{array}{c}\text { Net charge } \\
(\mathrm{pH7} .0)\end{array}$ & $\mathrm{Mr}(\mathrm{Da})$ & $\mathrm{pI}$ \\
\hline temporin-La & LLRHVVKILEKYLamide & +3 & 1623.08 & 9.70 \\
palustrin-Ca & GFLDIIKDTGKEFAVKILNN & +2 & 3303.97 & 8.79 \\
\hline
\end{tabular}

Table 1. Primary structure, net charge, molecular masses, and isoelectric points of temporin$\mathrm{La}$ and palustrin-Ca. The isoelectric point values were calculated using the ExPASy MW/pI tool (http://www.expasy.ch/tools/pi_tool.html). The molecular masses were determined by ESI-MS mass spectrometry.

\subsection{Antimicrobial and hemolytic activities of temporin-La and palustrin-Ca}

Minimum inhibitory concentrations (MICs) were determined to characterize antimicrobial activity (Table 2). Temporin-La and palustrin-Ca were both more effective against Grampositive than Gram-negative bacteria. Temporin-La exhibited stronger inhibition against S.aureus and S.suis than palustrin-Ca. The MIC of temporin-La against Staphylococcus aureus was $7.8 \mu \mathrm{g} / \mathrm{mL}$ and $15.6 \mu \mathrm{g} / \mathrm{mL}$ against Streptococcus suis, while MICs for palustrin-Ca against these microbes were $7.8 \mu \mathrm{g} / \mathrm{mL}$ and $31.25 \mu \mathrm{g} / \mathrm{mL}$. The antifungal activity [14,15] of temporin-La, as assed by the MIC was $31.25 \mu \mathrm{g} / \mathrm{mL}$. In contrast, palustrin-Ca was not nearly as potent as an antifungal agent with an MIC $>100 \mu \mathrm{g} / \mathrm{mL}$. Temporin-La showed no measurable hemolytic activity against rabbit erythrocytes at $250 \mu \mathrm{g} / \mathrm{ml}$. Similarly, palustrinCa showed little hemolytic activity $(0.25 \%$ at $250 \mu \mathrm{g} / \mathrm{ml})$.

\begin{tabular}{lcc}
\hline Bacterium & \multicolumn{2}{c}{$\begin{array}{c}\text { Antimicrobial activity (MIC } \mu \mathrm{g} / \mathrm{ml}) \\
\text { palustrin-Ca }\end{array}$} \\
\hline Gram-positive bacteria & $\mathrm{ND}$ & 30 \\
Listeria ATCC 54004 & 2.5 & 7.8 \\
S. aureus ATCC 25923 & 15.6 & 31.25 \\
S. suis 2 CVCC 606 & $>100$ & 30 \\
Bacillus subtilis ADB403 & 31.25 & $>100$ \\
Candida albicans ATCC10231 & & \\
Gram-negative bacteria & 15.6 & $>100$ \\
Salmonella ATCC 20020 & $>100$ & $\mathrm{ND}$ \\
E. coli ATCC 25922 & $>100$ & 60 \\
K. pneumoniae ATCC 700603 & 60 & 30 \\
P. aeruginosa ATCC 227853 & & 30 \\
\hline
\end{tabular}

Table 2. Antimicrobial activity of temporin-La and palustrin-Ca. The data represent mean values of three independent experiments. ND: not determined. 


\subsection{Temporin-La and palustrin-Ca possess strong anticancer activity}

The antitumor activity of temporin-La and palustrin-Ca was evaluated by MTT assay (Table 3). The $\mathrm{IC}_{50}$ of temporin-La against SMMC7721 cells was $1.384 \mu \mathrm{g} / \mathrm{mL}$, and palustrinCa was also a potent antitumor agent, with an $\mathrm{IC}_{50}$ of $0.951 \mu \mathrm{g} / \mathrm{mL}$ against SGC7901 cells.

\begin{tabular}{|c|c|c|}
\hline Tumor cell & $\begin{array}{l}\text { Antitumor } \\
\text { temporin-La }\end{array}$ & $\begin{array}{l}\mathrm{C}_{50}(\boldsymbol{\mu g} / \mathrm{mL}) \\
\text { palustrin-Ca }\end{array}$ \\
\hline SGC7901 & 2.755 & 0.951 \\
\hline MGC803 & 3.937 & 1.572 \\
\hline SMMC7721 & 1.384 & 1.077 \\
\hline BEL7402 & 2.670 & 1.375 \\
\hline HeLa & 4.685 & 1.202 \\
\hline
\end{tabular}

Table 3. Antitumor activity of temporin-La and palustrin-Ca.

\subsection{Electron microscopy}

Transmission electron microscopy was performed to evaluate the possible cytotoxic mechanisms of temporin-La and palustrin-Ca (Fig. 2). After $24 \mathrm{~h}$ treatment with temporin-La or palustrin-Ca at $10 \times \mathrm{MIC}$, HeLa cells exhibited significant damage, with breached membrane integrity, cytoplasmic leakage, mitochondria vacuolization, cristae loss, and blurred boundaries.

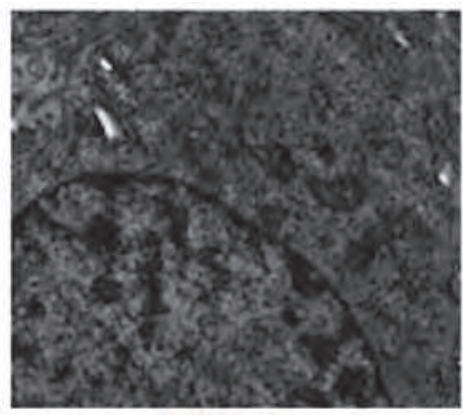

Hela(-)

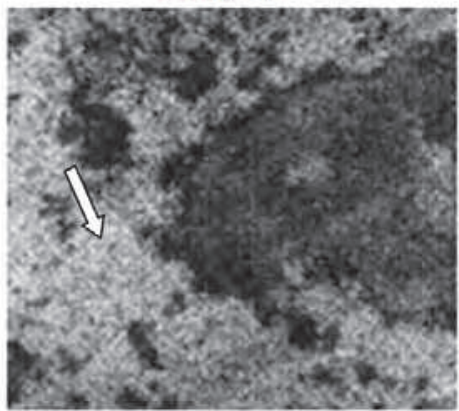

Hela (+)

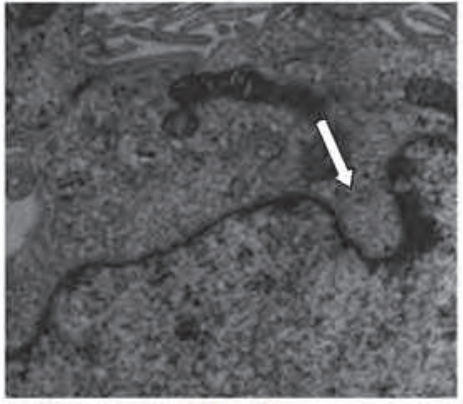

Hela(+)

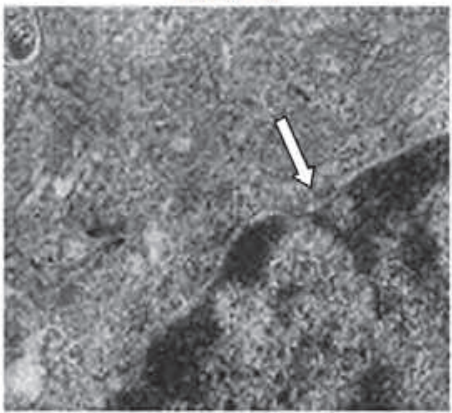

Hela(+)

Fig. 2. The cytotoxic activity of temporin-La and palustrin-Ca against Hela cell in vitro $(\times 20$ 000) Hela(-): untreated; Hela(+): temporin-La and palustrin-Ca treated. Peptides were used at 10 times the MIC. Arrows indicate the morphological changes. 


\section{Discussion}

Antimicrobial peptides demonstrate selective toxicity against tumor cells [16, 17], but the cytotoxic mechanisms remain poorly understood. Recent studies suggest that the cytotoxic mechanisms of antimicrobial peptides against bacteria are distinct for these antitumor activities. The sensitivity of tumor cells to antimicrobial peptides is far higher than the normal cells, thus allowing selective antitumor effects. This selective cytotoxicity may be due to the higher acidic phospholipid content of tumor cell membranes and the reduced integrity of the cytoskeleton system. Tumor cells can be inhibited and killed by direct contact with antimicrobial peptides, suggesting that the effect on cancer cells may be due to insertion of antimicrobial peptides into the plasma membrane. Membrane insertion causes bilayer melting and membrane puncture, leading to leakage of intracellular contents, mitochondria vacuolization, cristae loss, blurred boundaries, chromosomal DNA breakage, inhibition of chromosomal DNA synthesis, and other detrimental events associated with membrane damage. Another possible mechanism of antimicrobial peptides is the induction of apoptosis. Mai et al [18, 19] showed that local injection of the peptide DP1 into mice quickly induced tumor cell apoptosis. On the other hand, the protective immune response can be enhanced by antimicrobial peptides, as shown by the resistance to the invaded cancer cells conferred by humoral immunity. Temporin-La and palustrin-Ca demonstrated significantly different antimicrobial and antitumor efficacies against the tested battery of bacteria, fungi, and tumor cell lines, suggesting that the cytotoxic mechanisms may be at least partially distinct for different targets.

Temporin-La had higher antibacterial activity against Staphylococcus aureus, Streptococcus suis 2 and Salmonella than palustrin-Ca, with an MIC for Staphylococcus aureus of $2.5 \mu \mathrm{g} / \mathrm{mL}$. The $\mathrm{IC}_{50}$ against the gastric cancer cell line SMMC7721 was only $1.384 \mu \mathrm{g} / \mathrm{mL}$, and the $\mathrm{IC}_{50}$ values measured for all other tumor cells tested were lower than $5 \mu \mathrm{g} / \mathrm{mL}$. This is far below the concentration required for mammalian red blood cell hemolysis, indicating that temporin-La can inhibit the growth of some Gram-positive bacteria and cancer cells while not damaging the membranes of other healthy mammalian cells. Palustrin-Ca had stronger antibacterial activity against Staphylococcus aureus, Listeria, and Pseudomonas aeruginosa than temporin-La. The MIC against Staphylococcus aureus was $7.8 \mu \mathrm{g} / \mathrm{mL}$, and palustrin-Ca also exhibited promising inhibition against all the tumor cells studied, with $\mathrm{IC}_{50}$ values lower than $2 \mu \mathrm{g} / \mathrm{mL}$. The $\mathrm{IC}_{50}$ against the liver cancer cell line SGC7901 was only $0.951 \mu \mathrm{g} / \mathrm{mL}$, underscore the potential antitumor efficacy of palustrin-Ca. Temporin-La and palustrin-Ca are potential candidate antimicrobial and anticancer compounds that warrant further study.

\section{Acknowledgements}

This work was supported by the Chinese National Natural Science Foundation (30571416)

\section{References}

[1] Biedler JL, Riehm H .Cellular resistance to actinomycind in Chinese hamster cells in vitro: cross resistance, radioautographic and cytogenetic studies[J]. Cancer Res 1970; 30:1174-84. 
[2] Sunkyu Kima, Sukwon S. Kima, Yung-Jue Bangb. In vitro activities of native and designed peptide antibiotics against drug sensitive and resistant tumor cell lines[J]. Peptides, 2003, 24: 945-953.

[3] J. Doyle, C.S. Brinkworth, K.L. Wegener, nNOS inhibition, antimicrobial and anticancer activity of the amphibian skin peptide,citropin 1.1 and synthetic modifications. The solution structure of a modified citropin 1.1[J], Eur. J. Biochem. 2003, 27:1141-1153.

[4] H.-S. Won, M.-D. Seo, S.-J. Jung.Structural determinants for the membrane interaction of novel bioactive undecapeptides derived from gaegurin 5[J], J. Med. Chem. 2006, 49: 4886-4895.

[5] L. Cruz-Chamoro, M.A. Puertollano, E. Puertollano.In vitro biological activities of magainin 1 alone or in combination with nisin[J], Peptides .2006,27:1201-1209.

[6] Roaek T, Wegener KL , Bowie J H. The antibiotic and anticancer active aurein peptides from the Australian bell frogs Litoria aurea and Litoria raniformis [J]. European Journal of Biochemistry , $2000,267: 5330 \sim 5341$.

[7] M. Zasloff, Magainins, a class of antimicrobial peptides from Xenopus skin: isolation, characterization of two active forms, and partial DNA sequence of a precursor[J], Proc. Natl. Acad. Sci. U. S. A. 1987,84:5449-5453.

[8] David W. Hoskin, Ayyalusamy Ramamoorthy. Studies on anticancer activities of antimicrobial peptides[J]. Biochimica et Biophysica Acta, 2008,1778 :357-375.

[9] Rozek T, Wegener KL, Bowie JH, et al. The antibiotic and anticancer active aurein peptides from the Australian Bell Frogs Litoria aurea and Litoria raniformis[J]. Eur J Biochem,2000, 267: 5330-5331.

[10] Xu ND, Zhong L, Zhang W, et al. The relationship between structure and antibacterial activity of cationic antimicrobial peptides [J]. Chin J Public Health, 2005, 21(9): 1143.

[11] Zhao RL, Han JY, Han WY. Molecular Cloning of Two Novel Temporins From Lithobates catesbeianus and Studying of Their Antimicrobial Mechanisms[J].Progress in Biochemistry and Biophysics .2009, 36(8): 1064 1070.

[12] G ill S C, von Hippel PH. Calculation of protein extinction coefficients from amino acid sequence data[J]. Anal Biochem. 1989, 182(2): 319-26.

[13] Bignami GS. A rapid and sensitive hemolysis neutralization assay for palytoxin. Toxicant 1993; 31: 817-20.

[14] Yashuhara T, Nakajima T, Erspamer V, Falconieri-Erspamer G, Tukamoto Y, Mori M. Isolation and sequential analysis of peptides in Rana Erythraea skin. In: Y. Kiso, Editor, Peptide Chemistry 1985, Protein Research Foundation, Osaka (1986), pp. 363-368.

[15] Simmaco M, Mignogna G, Canofeni S, Miele R, Mangoni ML, Barra D. Temporins, antimicrobial peptides from the European red frog Rana temporaria. Eur J Biochem 1996; 242:788-92.

[16] Matsuzaki K, Harada M, Funakoshi S, Fuji N, Miyajima K. Physicochemical determinants for the interactions of magainins 1 and 2 with acidic lipid bilayers[J]. Biochem. Biophys. Acta. 1991, 1063: 162-170.

[17] Frank Schweizer. Cationic amphiphilic peptides with cancer-selective toxicity[J].European Journal of Pharmacology, 2009,625:190-194. 
[18] Mai JC, et al. A proapoptotic peptide for the treatment of solid tumors [J]. Cancer Res, 2001, 61: 7709-7712

[19] Mi Z, et al. Identification of a synovial fibroblast-specific protein transduction domain for delivery of apoptotic agents to hyperplastic synovium [J]. Mol Ther, 2003, 8(2): 295-305. 


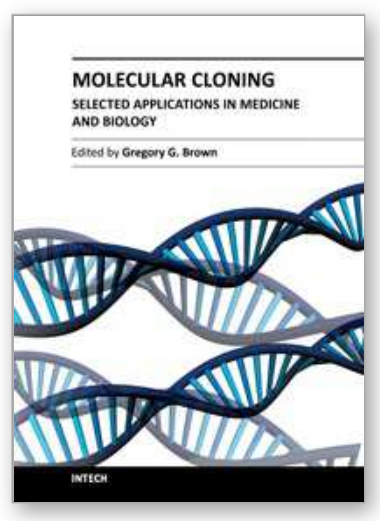

\author{
Molecular Cloning - Selected Applications in Medicine and Biology \\ Edited by Prof. Gregory Brown
}

ISBN 978-953-307-398-9

Hard cover, 324 pages

Publisher InTech

Published online 12, October, 2011

Published in print edition October, 2011

The development of molecular cloning technology in the early 1970 s created a revolution in the biological and biomedical sciences that extends to this day. The contributions in this book provide the reader with a perspective on how pervasive the applications of molecular cloning have become. The contributions are organized in sections based on application, and range from cancer biology and immunology to plant and evolutionary biology. The chapters also cover a wide range of technical approaches, such as positional cloning and cutting edge tools for recombinant protein expression. This book should appeal to many researchers, who should find its information useful for advancing their fields.

\title{
How to reference
}

In order to correctly reference this scholarly work, feel free to copy and paste the following:

Rui-Li ZHAO, Jun-You HAN, Wen-Yu HAN, Hong-Xuan HE and Ji-Fei MA (2011). Effects of Two Novel Peptides from Skin of Lithobates Catesbeianus on Tumor Cell Morphology and Proliferation, Molecular Cloning - Selected Applications in Medicine and Biology, Prof. Gregory Brown (Ed.), ISBN: 978-953-307-398-9, InTech, Available from: http://www.intechopen.com/books/molecular-cloning-selected-applications-in-medicine-andbiology/effects-of-two-novel-peptides-from-skin-of-lithobates-catesbeianus-on-tumor-cell-morphology-and-prol

\section{INTECH}

open science | open minds

\section{InTech Europe}

University Campus STeP Ri

Slavka Krautzeka 83/A

51000 Rijeka, Croatia

Phone: +385 (51) 770447

Fax: +385 (51) 686166

www.intechopen.com

\section{InTech China}

Unit 405, Office Block, Hotel Equatorial Shanghai

No.65, Yan An Road (West), Shanghai, 200040, China

中国上海市延安西路65号上海国际贵都大饭店办公楼405单元

Phone: +86-21-62489820

Fax: +86-21-62489821 
(C) 2011 The Author(s). Licensee IntechOpen. This is an open access article distributed under the terms of the Creative Commons Attribution 3.0 License, which permits unrestricted use, distribution, and reproduction in any medium, provided the original work is properly cited. 